\title{
مقالم يَوهشهى
}

\section{تعيين تاثيراستارتر ماست وسويه يروبيوتيكى لاكتوباسيلوس كازئى بر كاهش آفلاتو كسين M1 د در ماست}

\author{
مرسا عليداد "، على محمدى ثانى '، فائزه تجلى

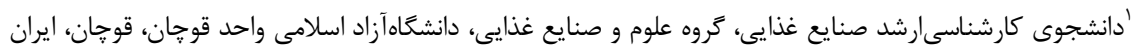

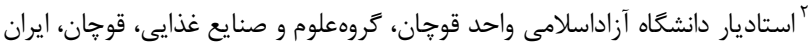

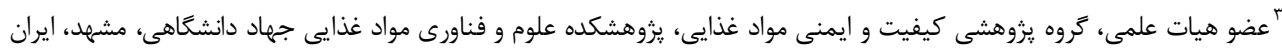

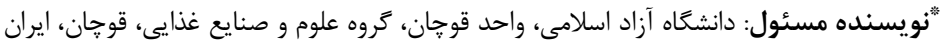 \\ m.alidad@yahoo.com : بست الكترونيك \\ وصول:Irq/T/RF
}

جكيده

زمينه و هدف: ماست يكى فرآورده تخميرى /ست كه به وسيله تخمير لاكتيكى توسط باكترىهاى آغازكر ماست بدست مئ آيد. كه در

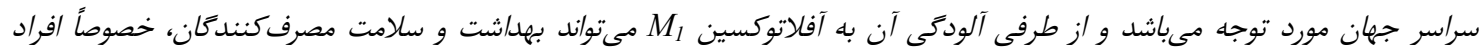

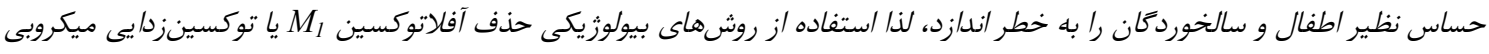

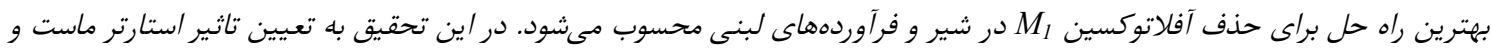

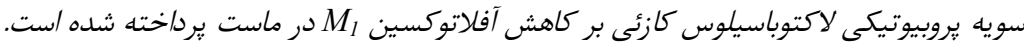

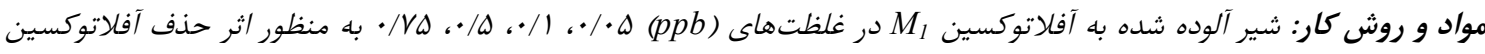

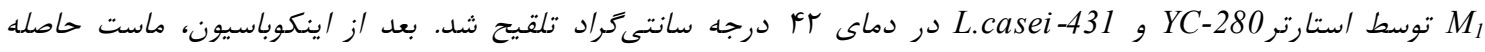

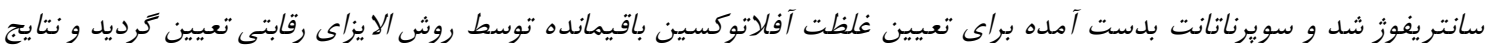

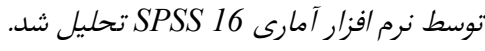

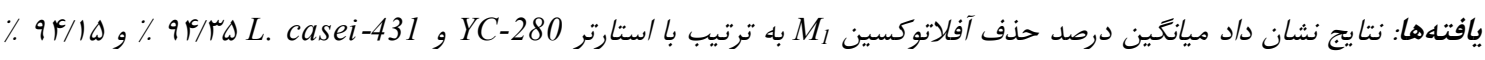
نتيجه كيرى: استارتر ماست و سويه بروبيوتيكى لاكتوباسيلوس كازئى مىتواند به عنوان يكى روش /يمن، بلدون از دست رفتن ارزش تغذيةاى براى حذف آلودكى مورد /ستفاده قرار كيرد.

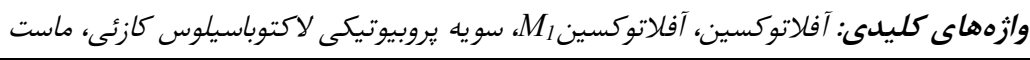

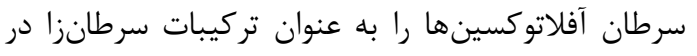
مقدمه

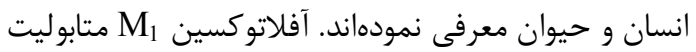
آفلاتوكسينها از مهمترين سموم قارجى محسوب مى - مونى

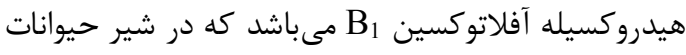

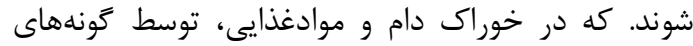

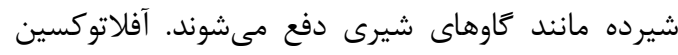

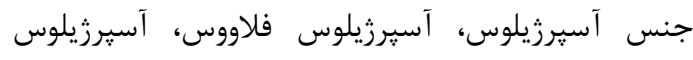

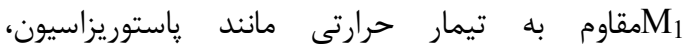

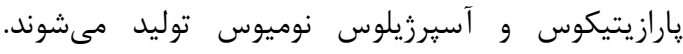
استريليزاسيون است و نيمه عمر طولانى آفلاتوكسين و واستورئرسيون

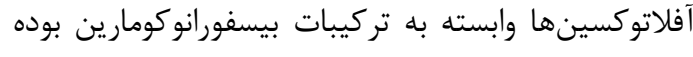

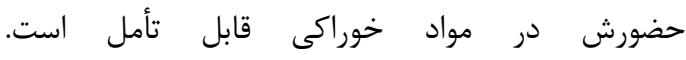

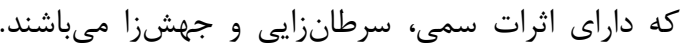

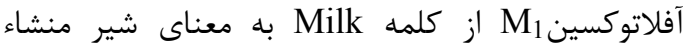

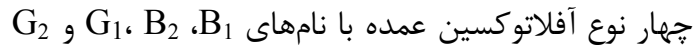

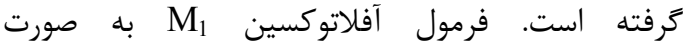

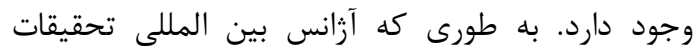




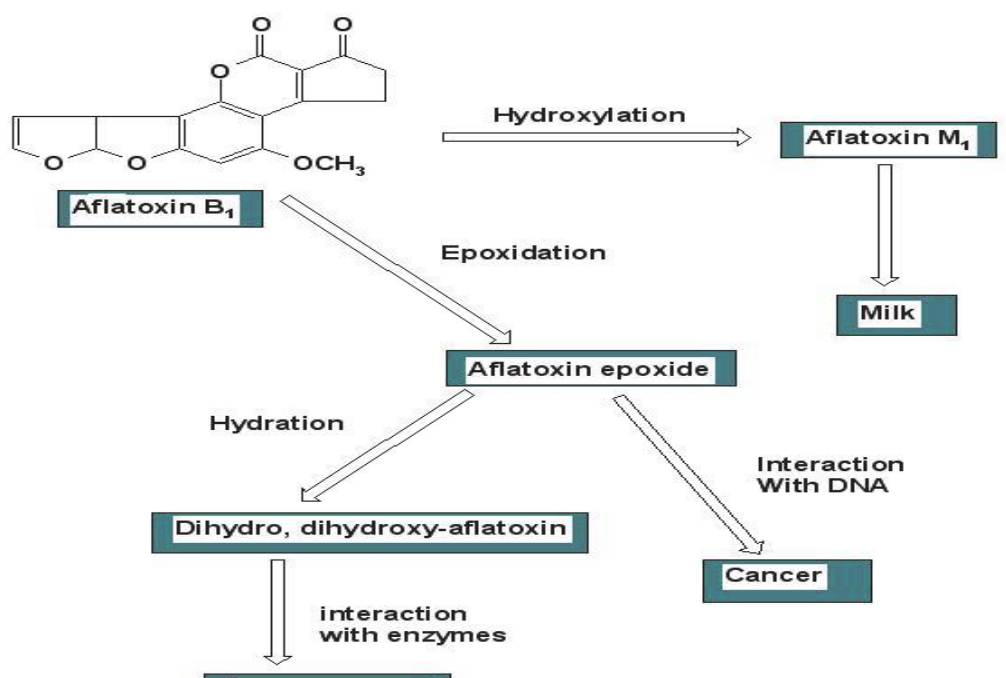

Acute toxicity

AFB 1 AFM

آفلاتوكسين (AFM)

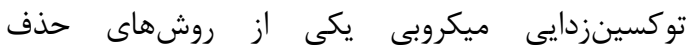

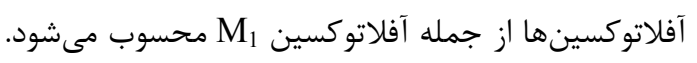

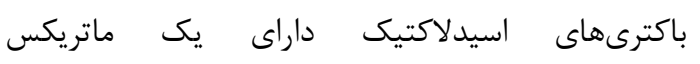
ييتيدو گليكان مىباشند، كه تركيب عمده ساختمان ديواره سلولى است و تركيبات ديخر آن اسيدتيكوئيك، اسيد

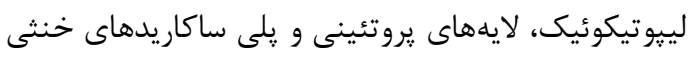
است. اين تركيبات عملكردهاى مختلفى دارند. اسيد

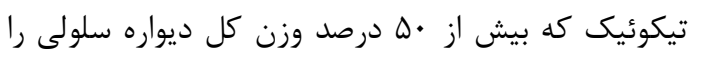
شامل مىشود داراى خاصيت هيدروفوبى بالايى مى باشد دئيد كه در مكانيسم جذب سطحى توكسين و اتصال به آن

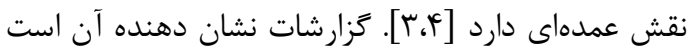
كه برخى از نزادهاى باكترىهاى خانواده اسيد لاكتيك از طريق جذب سطحى آفلاتوكسينها به ديواره سلولى خود مىتوانند در حذف آفلاتوكسينها موثر باشند. در اين

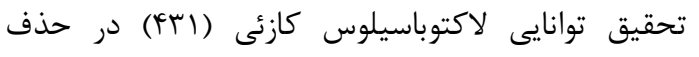
آفلاتوسين M1 مورد بروسى قرارگرفت. لاكتوباسيلوس كازئى يكى از انواع يروبيوتيكها است كه كاربرد وسيعى ئى

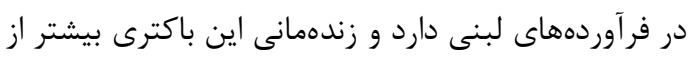

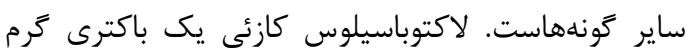

C است ( شكل (). اين سم از طريق علوفه وارد بدن دام مى گردد آنگاه در شكمبه يستانداران توسط

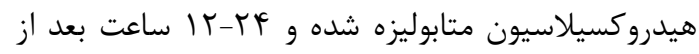
اولين بلع آفلاتوكسين

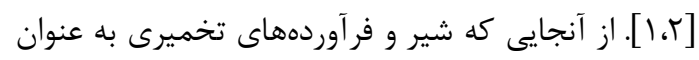

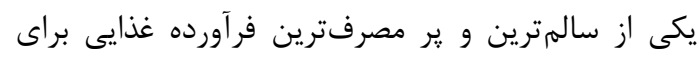
مصرف كنندگان، خصوصاً افراد حساس نظير اطفال و ورئ سالخوردگان است توجه به جنبههاى كيفى و سلامتزايى

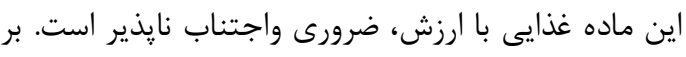
طبق قوانين وضع شده توسط FDA حداكثر مقدار مجاز آفلاتوكسين عمدهاى در اين زمينه موجود است، نتايج تحقيقات نشان داده است كة استفاده از روشهاى بيولوزيكى حذف رمينه آفلاتوكسين M1 يا توكسينزدايى ميكروبى بهترين راه حل براى حذف آفلاتوكسين M1 در شير و فرآوردههاى لبنى محسوب مىشود [ب]. لاكتوباسيلوسها، راه حل مناسب براى كاهش دسترسى زيستى آفلاتوكسينها است. روشهاى فيزيكى، شيميايى زيادى براى رفع آفلاتوكسينها در مواد غذايى مورد

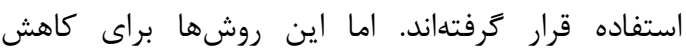


شير دردماى سو درجه سانتى با استارتر LC-280 و Lb.casei-431 (از شركت كرستين هانسن خريدارى شد) در دماى Fr Pr درجه سانتى

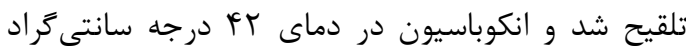
به مدت ץبعد در دماى f أدرجه يخجال ذخيره سازى شد. در نهايت

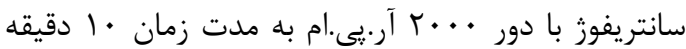

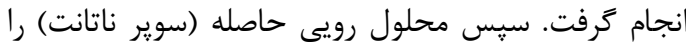
در ميكروتيوڤ به كمك سميلر جمع آورى كرده و اندازه -

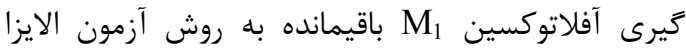

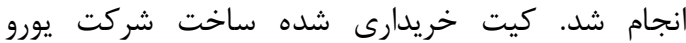
يروكسيما و روش بكار رفته بر يايه الايزا رقابتى مسقيه

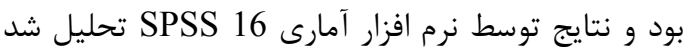

$[1 \cdot 911]$

يافتهها

اثر استارتر $\quad$ MC-280 بر كاهش آفلاوكسين M

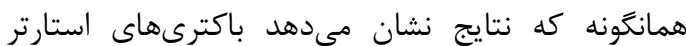
ماست

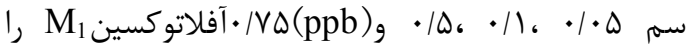
كاهش دادند و اثر كاهش دهندگى آنها در غلظتهاى مختلف معنى دار بوده و بيشترين درصد حذف مربوط به

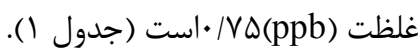
اثر استارتر و سويه : يروبيوتيكى لاكتوباسيلوس كازئى بركاهش آفلاوكسين M1 : نتايج نشان مىدهد كه در بر حضور باكترى لاكتوباسيلوس كازئى(Lb.Casei-431)

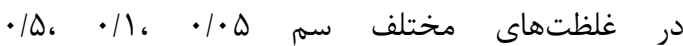

مثبت، مزوفيل، هموفرمنتاتيو اجبارى، ميكروآئروفيل، كاتالاز منفى و فاقد اسيور بوده و ظرفيت بالايى در توليد اسيد دارد. در مطالعات متعدد اثرات سودمند آن از جمله مقاومت به اسيد معده و نمكهاى صفراوى، قدرت جسبندگى به سلولهاى مخاط روده، مهار فعاليت باكترىها و توليد مواد ضد ميكروبى به اثبات رسيده است [ه،ه]. بهترين نتايج حذف يا كاهش آفلاتوكسين تا به به حال با استفاده از روش تخمير به دست آمده است. ماست يك فرآورده لبنى تخميرى زل مانندى است كه به وسيله تخمير لاكتيكى توسط دو باكترى آغازگر ماست لاكتو

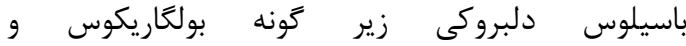

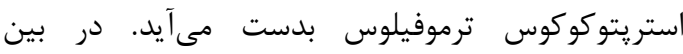

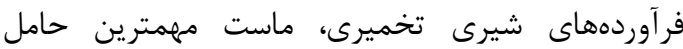
باكترىهاى يروبيوتيك و عامل انتقال آن به مصرفكنيده مىباشد. ماست منبع غنى از كلسيم است. تخمير اسيدى

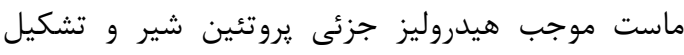

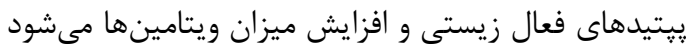
با افزودن ميكروار گانيسمهاى يروبيوتيك (مانند گونههاى

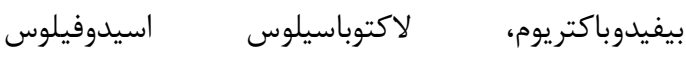
ولاكتوباسيلوس كازئى) خصوصيات سلامت بخش ماست افزايش مى يابد [V،،.9.] روش كار

شير بازسازى شده از شير خشك اسكيم (مرك آلمان) با آفلاتوكسين M1 (از شركت كيميا گران شيمى صنعت

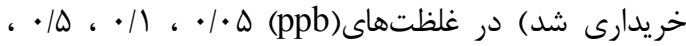

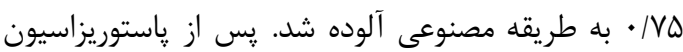

جدول ا: مقايسه ميانگين حذف آفلاتوكسين M با غلظتهاى مختلف توسط استارتر YC-280 (مقادير به صورت ميانكَن گزارش ترديده است)

\begin{tabular}{|c|c|c|c|c|c|c|c|c|c|c|}
\hline سطح & كمترين & بيشترين & & ميانگين & & & (ppb) & آفلاتو كسـ & غلظن & \\
\hline غلظت & & & & $Y C-280$ & & $\cdot / V \Delta$ & $\cdot 10$ & $\cdot 11$ & $\cdot 1 \cdot \Delta$ & \\
\hline$\cdot 1 \cdot \cdots 1$ & NG/TG & $99 / \cdot 9$ & $\cdot 1 \cdot V r$ & $q \mu / r \Delta^{a}$ & . & $99 / 9^{d}$ & $q \wedge / 0 q^{c}$ & $q \mu / q^{b}$ & $\Lambda q / \mu \varphi^{a}$ & حذف آفلاتوكسين \\
\hline
\end{tabular}

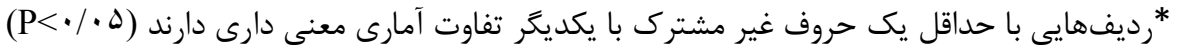




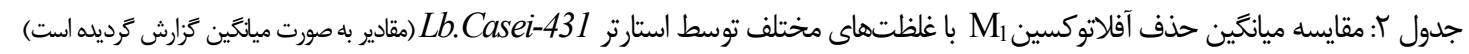

غلظت آفلاتوكسين (ppb)

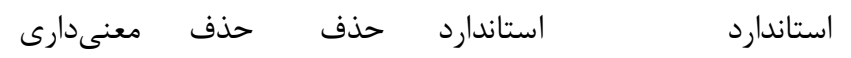

\begin{tabular}{ccccc}
\hline Lb.Casei- & $\cdot / \mathrm{V \Delta}$ & $\cdot / \Delta$ & $\cdot / 1$ & $\cdot / \cdot \Delta$ \\
\hline 431 & 0
\end{tabular}

حذف آفلاتوكسين

(درصد)

(P<•/•ه (ديفهايى با حداقل يك حروف غير مشترك با يكديكر تفاوت آمارى معنى دارى دارند

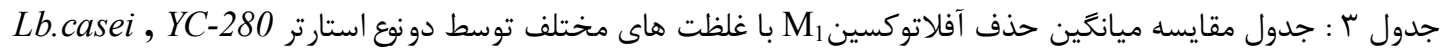

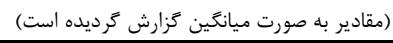

غلظت آفلاتوكسين (ppb)

\begin{tabular}{|c|c|c|c|c|c|c|c|c|c|c|c|}
\hline غلظت ×نوع & نوع & غلظت & & $\begin{array}{c}\text { Lb.Casei- } \\
431\end{array}$ & $\begin{array}{l}Y C- \\
280\end{array}$ & & $\cdot / V \Delta$ & $\cdot / 0$ & $\cdot 11$ & $\cdot 1 \cdot \Delta$ & \\
\hline$\cdot \mid 1991$ &.$/ 499$ & $\cdot 1 \cdot \cdots 1$ & $.11 \cdot 9$ & $94 / 10^{a}$ & $q 4 / r \Delta^{a}$ & $.119 \mathrm{~V}$ & $99 / \cdot r^{d}$ & $9 \Lambda / \Delta \Delta^{c}$ & $9 \pi / 1 V^{b}$ & $\Lambda \varepsilon / r^{a}$ & حذف آفلاتوكسين \\
\hline
\end{tabular}

رديفهايى با حداقل يك حروف غير مشترك با يكديكر تفاوت آمارى معنى دارى دارند (ه>••(•)

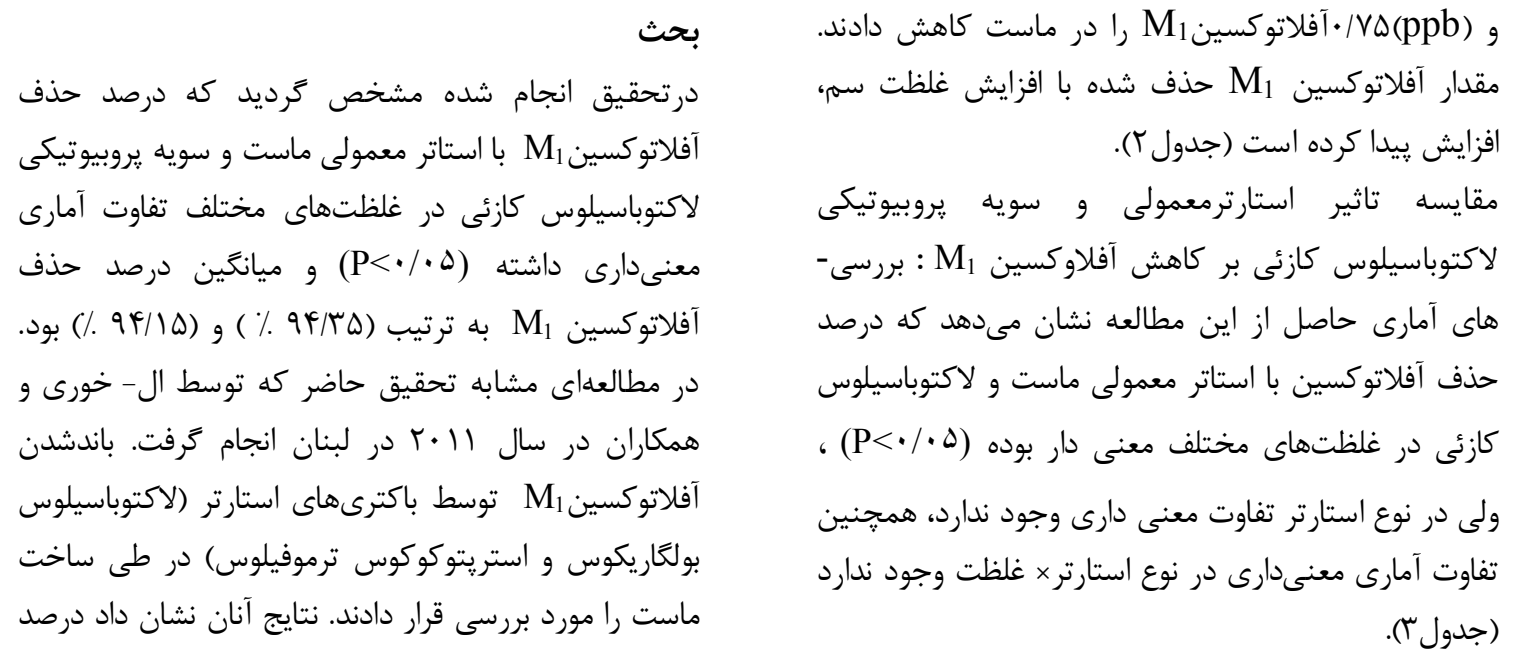




\section{نتيجه گَيرى}

حضور آفلاتوكسين در لبنيات يك مشكل جدى و مهرم براى

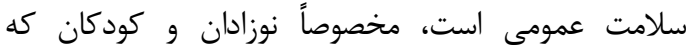
بيشترين مصرف كننده اين محصولات بشمار مىروند. براى كاهش آفلاتوكسين در شير، كنترل تغذيه دامهاى شيرده كه

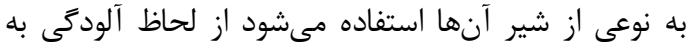
آفلاتوكسين (AFM 1 بايد مورد توجه قرار كيرد. بهترين نتايج بدست آمده از اين مطالعه نشان مىدهد مئد

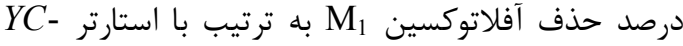

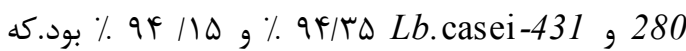
بعد از تخمير توسط باكترىهاى استارتر ماست و سويه يروبيوتيكى لاكتوباسيلوس كازئى مقدار آفلاتوكسين M

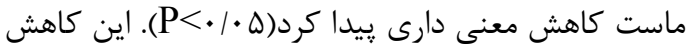

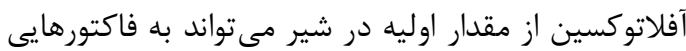

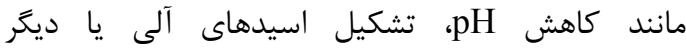
محصولاتى كه در طى تخمير ايجاد مىشود، يا حتى الى الئ

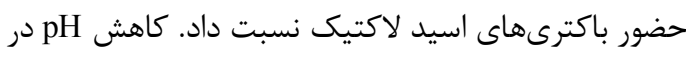
طى تخمير باعث تغيير در ساختمان يروتئينهاى شير

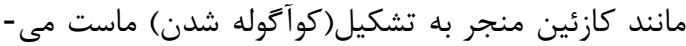
شود. در واقع تغيير ساختمان كازئين در طى تشكيل

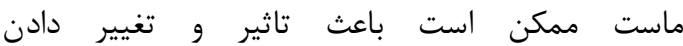
آفلاتوكسين M شود كه در نهايت موجب جذب يا يوشاندن سم در ماست مى شعود.

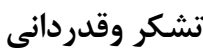

بدين وسيله از گروه يزوهشى كيفيت و ايمنى مواد غذايى يزوهشكده علوم و فناورى موادغذايى جهاد دانشخاهى مشهد كه هزينه انجام اين طرح تحقيقاتى را متقبل شدند و همكارى صميمانه كليه كاركنان محترم يزوهشكده اقبال كه در انجام اين يزوهش يارى نمودند. تشكر و قدردانى مى كرد.
باند كردن لاكتوباسيلوس بولكاريكوس (NV/9. /) درمقايسه

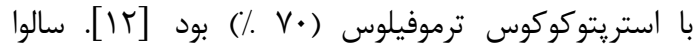

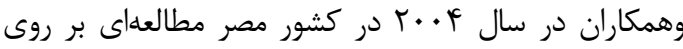
ماست ساده و ماست هويج و همجنين به بررسى تاثير عصاره

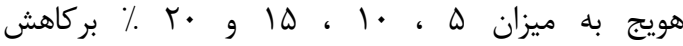

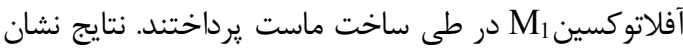

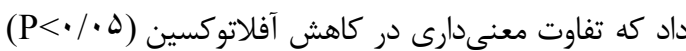
بين ماست ساده و ماست هويج وجود دارد. بيشترين درصد كاهش آفلاتوكسين

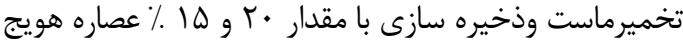

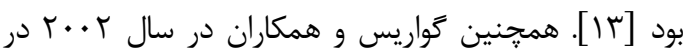

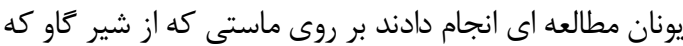
به طور مصنوعى با آفلاتوكسين

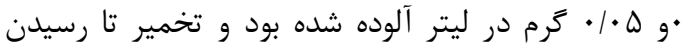

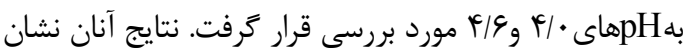
داد كه درصد كاهش مقدار اوليه از آفلاتوكسين درشير rا و T T درصد همجنين در انتهاى تخمير و در

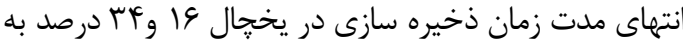

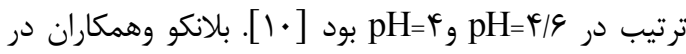
سال 1911 در اسيانيا به بررسى توليد آفلاتوكسين در ماست محلى و رشد قارج، را در ماست مورد بررسى قرار دادند. نتايج نشان داد كه ماست يك بازدارنده خوب براى آنائ آفلاتوكسين است. دو فاكتور خاص جالب توجه: (a) تاثير لاكتيك اسيد

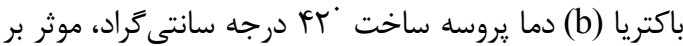

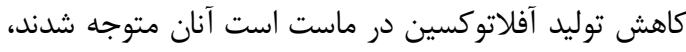

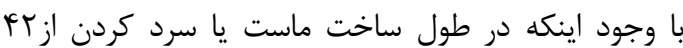
درجه بهأ درجه شرايط لازم ومورد نياز براى رشد قارئ داست ساست

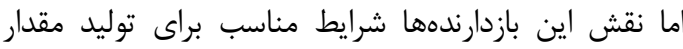

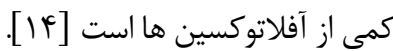

\section{References}


1. Creppy E.E, update of survey, regulation and toxic effects of mycotoxins in Europe, Toxicology Letters 2002; (27): 19-28.

2. Cavaliere C, Foglia P, Pastorini E, Samperi R, Lagana A, Liquid chromatography/tandem mass spectrometric confirmatory method for determining aflatoxin $\mathrm{M}_{1}$ in cow milk comparison between electrosray and atmospheric pressure photo ionization sources, Journal of chromatography 2006: 69-78.

3. Kabak B, Var I, Factors affecting the removal of aflatoxin $\mathrm{M}_{1}$ from food model by Lactobacillus and Bifidobacterium strains, Journal of Environmental Science and Health Part B 2008; (43): 617-624.

4. Pierides M, El-Nezami H, Peltonen K, Salminen S, Ahokas J, Ability of dairy strains of lactic acid bacteria to bind aflatoxin $\mathrm{M}_{1}$ in a food model, Journal Food Protection 2000; (63): 645-650.

5. Mirlohi M, Soleimanian-zad S, Sheikh Zeinodin M, Fazeli H, Enumeration of lactobacill in the fecal flora of infant using two different modified de-man rogosa sharpe media under aerobic and an aerobic incubation Pak, J Biol Sci 2008; (6): 81-876.

6. Mishra V, Prasad D.N, Application of in vitro methods for selection of Lactobacillus casei strains as potential probiotics, International Journal of Food Microbiology 2005; (103): 109-115.

7. Bari M, Ashrafi R, Alizadeh $M$, Rofehgarineghad L, Effects of different of yogurt starter or probiotic bacteria, storage time \& different concentration of cysteine on the microflora characteristics of Bio-Yogurt,
Research Journal of Biological Science 2009; (2): 137-142.

8. Mohebbi M, Ghoddusi H.B, Rheological \& sensory evaluation of yogurts containing probiotic cultures, Journal of Agriculture Science Technology 2008; (10): 147-155.

9. Playe M.J, Bennett L.E, Smithers G.W, The Australin Journal of Dairy Technology 2003: 242-264.

10.Govaris A, Roussi V, Koidis P.A, Botsoglou N.A, Distribution and stability of aflatoxin $\mathrm{M}_{1}$ during production and storage of yoghurt, Food Additives and Contaminants 2002; (11): 1043-1050.

11. Sarimehmetoglu B, Kuplulu O, Binding ability of aflatoxin $\mathrm{M}_{1}$ to yoghurt bacteria, Ankara Univ Vet Fak Dreg 2004; (51): 195198.

12.El-Khoury A, Atoui A, Yaghi J, Analysis of aflatoxin $\mathrm{M}_{1}$ in milk and yogurt and $\mathrm{AFM}_{1}$ reduction by lactic acid bacteria used in Lebanese industry, Food Control 2011; (22): 1695-1699.

13. Salwa A.A, Galal E.A, Elewa N.A, Carrot Yogurt: Sensory, Chemical, Microbiological Properties and Consumer Acceptance, Pakistan, Journal of Nutrition 3 2004; (6): 322330.

14.Blanco L.J, Dominguez L, Gomezlusia E, Garayzabal J.F, Goyashe J, Suarez G, Experi mantal aflatoxin production in commercial yoghurt, Z Lebensm Unters Forsc 1988; (186): 218-222.

15.Berg $\mathrm{T}$, How to establish international limits for mycotoxins in food and feed. Food Control 2003; (14): 219-224. 
Original Article

\section{Evaluation of starter bacteria and lactobacillus casei effects on aflatoxin $M_{1}$ in Yoghurt}

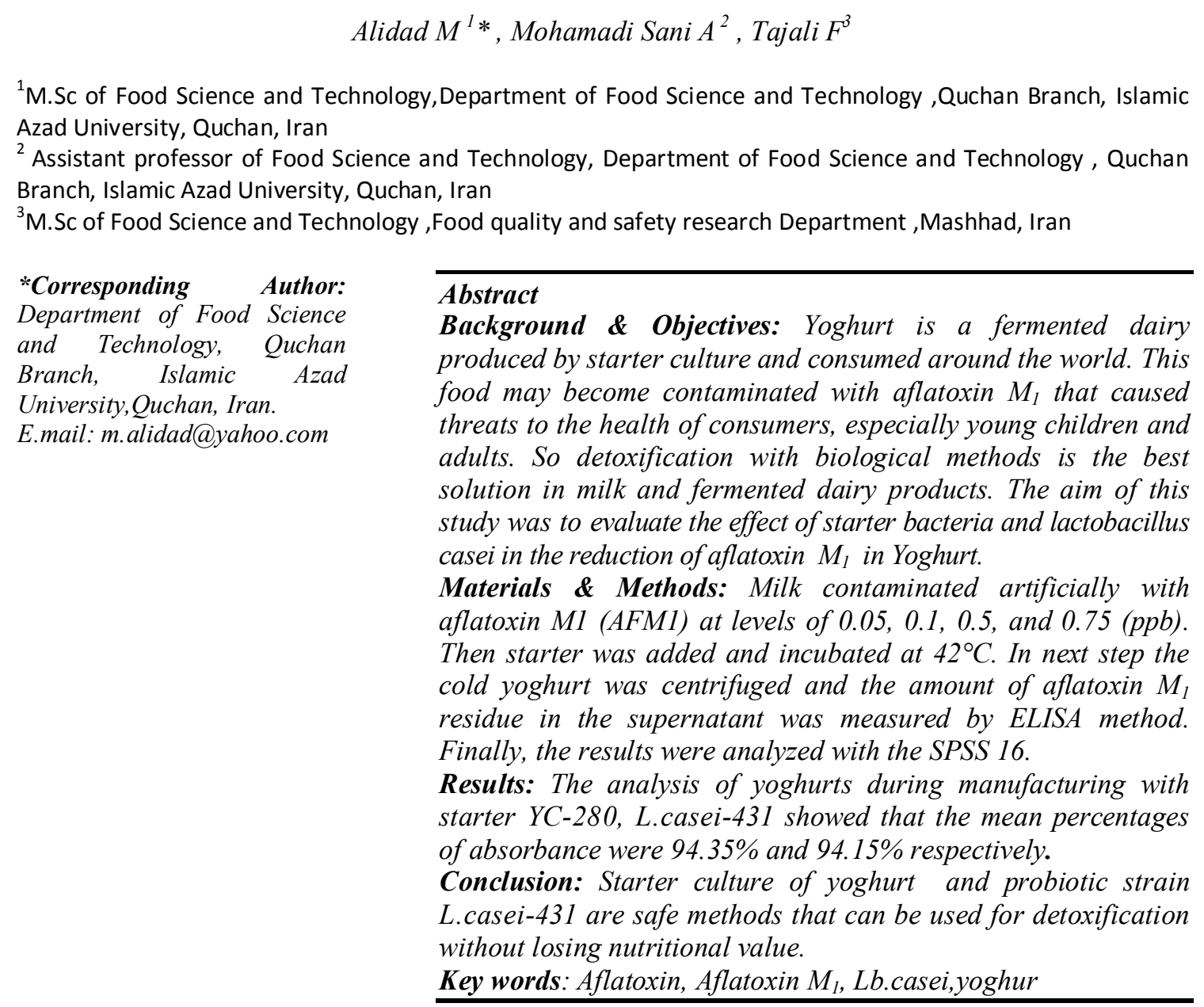

Submitted: 15Oct 2012

Revised: 5 Nov 20112

Accepted: 27 Nov 2012 